九州大学学術情報リポジトリ

Kyushu University Institutional Repository

\title{
Agricultural Mechanization in Rural Area of Lao PDR : A Case Study of Farm Tractorization
}

\section{Latmany, Phonesavanh}

Laboratory of Farm Management, Division of International Agricultural Resource Economics and Business Administration, Department of Agricultural and Resource Economics, Graduate School of Bioresource and Bioenvironmental Science, Kyushu University

Shinkai, Shoji

Faculty of Agriculture, Kyushu University

Hotta, Kazuhiko

Faculty of Agriculture, Kyushu University

Nanseki, Teruaki

Faculty of Agriculture, Kyushu University

https://doi.org/10.5109/12878

出版情報：九州大学大学院農学研究院紀要. 53 (2)，pp.593-599，2008-10-28. Faculty of Agriculture, Kyushu University

バージョン :

権利関係 : 


\title{
Agricultural Mechanization in Rural Area of Lao PDR: A Case Study of Farm Tractorization
}

\author{
Phonesavanh LATMANY'*, Shoji SHINKAI ${ }^{2}$, Kazuhiko HOTTA ${ }^{2}$ \\ and Teruaki NANSEKI ${ }^{2}$
}

\author{
Laboratory of Farm Management, Division of International Agricultural and Resource Economics and \\ Business Administration, Department of Agricultural and Resource Economics, \\ Graduate School of Bioresource and Bioenvironmental Science, \\ Kyushu University, Fukuoka 812-8581, Japan \\ (Received June 27, 2008 and accepted July 16, 2008)
}

\begin{abstract}
In an attempt to emphasize the impact of farm tractorization in rural area, the research has been carried out in PhaOudom, recognized as one of the poorest districts in Laos. This paper is aimed at providing a comparative analysis among tractor-using farmers, namely, tractor-owning farmers and non-tractor-owning farmers, and negative effect of tractorization by custom hire on the food security. The analysis uses 2007 cross-sectional survey data on 88 randomly selected rice farming households. Descriptive and variance analyses show that tractor-owning farmers are better in terms of mechanization level, rice and livestock production (larger area and larger herd of animals). The result from regression analysis suggests that tractor-owning farmers have increasing returns to scale while non-tractor-owning farmers have constant returns to scale. Moreover, tractor-owning farmers obtain extra paddy from hiring out their tractor-about $1300 \mathrm{~kg}$ in 2007. As a result, they have more annual farm income than non-tractor-owning farmers. About $90 \%$ of non-tractor-owning farmers acquired the use of tractor for tillage operation by custom hire, and about $70 \%$ of them paid by paddy due to lack of cash. Approximately $30 \%$ of total production was paid as the fee-everything included. This affects largely the security of rice consumption of these farmers, and $66 \%$ of them ended up rice shortage.
\end{abstract}

\section{INTRODUCTION}

The Lao PDR, shortly called 'Laos' is a landlocked and mountainous country with the total area of $236,800 \mathrm{Km}^{2}$ and population of approximately 5.6 million. The distribution of population is, however, $23 \%$ urban and 77\% rural (UNDP, 2006). Accounting for $47 \%$ of GDP and employing $77 \%$ of labor force, agriculture is one of the most important sectors in the economy. However, only about $40 \%$ of farm households produce for market, and $60 \%$ produce at subsistence level (UNDP, 2006).

Farm tractorization in Laos has commenced in the 1960 s by the introduction of large tractors imported from the former Soviet Union (Singh et al., 2001). According to Lao Expenditure and Consumption Survey 1997/98 (LECS 2), tractor was owned by 10\% of households in 1998. Lao Agricultural Census 1998/99 indicated that only $29 \%$ of farm households in total used farm machinery, and the most mechanized farms were in Vientiane capital, where $77 \%$ used farm machinery and $67 \%$ used tractor (MAF, 2000). In 2003, tractor was owned by $19 \%$ of households- $4 \%$ for four-wheel and $15 \%$ for two-wheel. In addition, two-wheel tractor is most concentrated in rural area with access road, urban

\footnotetext{
1 Laboratory of Farm Management, Division of International Agricultural Resource Economics and Business Administration, Department of Agricultural and Resource Economics, Graduate School of Bioresource and Bioenvironmental Science, Kyushu University

2 Faculty of Agriculture, Kyushu University

* Corresponding author (E-mail: kilatmany@yahoo.com)
}

area and rural area without access road, 19\%, 11\% and $8 \%$, respectively (LECS 3 ).

In rural area, two-wheel tractor is widely used due to its cheaper cost and multi-functionalities. Considering the fact that the average farm size in Laos is about 1.62 ha (MAF, 2000), two-wheel tractor is more costefficient than four-wheel-current price is approximately 15 million kip for $8.5 \mathrm{Hp}$ two-wheel tractor and 350 million kip for $95 \mathrm{Hp}$ four-wheel tractor. The principal use of two-wheel tractor is to plow and harrow the paddy field to prepare the land. When attached with trailer and rubber tires, two-wheel tractor is also modified as a mode of transportation which is apparently popular; it is utilized to carry many things like crops, woods, water etc. Moreover, farmers use its engine to generate the power for consumption or income-generating activities. Therefore, two-wheel tractor is playing a crucial role in rural area not only on-farm but also offfarm activities. Binswanger (1978) affirmed that nonagricultural benefits of the tractor should not be underestimated.

Machinery can be acquired through ownership (individual or joint), exchange work, custom hire, and rent or lease (Sydney C. James and Phillip R. Eberle, 2000, pp: 316-319). Tractorization, therefore, does not only mean ownership, but any form of obtaining the use of tractor. In rural area of Laos, however, typical introduction of tractor could be done through three ways-ownership (individual or joint), custom hire and others (exchange work or borrowing from relatives). Apparently, the most popular forms of gaining the use of tractor are through ownership for a farmer with cash income and custom hire for a smallholder farmer. 
Despite growing number of farmers using tractor for tillage operation, the available information on its economic viability at farm level is very scarce. Both tractorowner and tractor-hirer use a tractor for tillage operation, but the quality of jobs is not equal resulting in presumably different productivity. On the other hand, the high fee of tractor hire, often paid by paddy, is worrisome for the tractor-hiring farmers especially smallholder farmers. It could be one of the factors affecting rice consumption in the household.

Therefore the objectives of this study are firstly to provide a comparative analysis among farmers who tractorized their farms by ownership and non-ownership. Particular attention is paid on the impact of tractorization by ownership on mechanization level, crop and livestock production, and gross farm income. Secondly, regression analysis will deal with the difference between resource use and productivity among the farmers in rice production. Finally, the characteristics and impact of tractorization on food security of tractor-hiring farmers is elaborated in order to verify the tractor hire as one of the factors causing rice shortage. The survey was conducted in November, 2007 in Bokeo province which shows the highest percentage of households owning two-wheel tractor in the northern region (LECS 3). The analysis uses data on 88 rice farmers who used tractor for tillage operation of paddy field regardless of ownership or non-ownership. Tractor in this study is largely referred to as two-wheel tractor (power tiller).

\section{STUDY AREA AND METHODOLOGY}

Having been recognized as one of the poorest districts in Laos, PhaOudom, one of the districts in Bokeo province, is the area under this study. The total area is $1,579 \mathrm{~km}^{2}$, of which $65 \%$ is mountainous. Totally, there are 94 villages, more than half of which is very poor. The total population is 36,400 inhabitants.

People in this area rely solely on rice production for cereal consumption, and rice and cash crop for income in addition to livestock and forest product gatherings. In 2007, the area under wet-season lowland rice production is 1,900 hectares whereas dry-season lowland rice production area is only 327 hectares. A total area of 1,600 hectares is devoted to upland rice production which is slightly lower than the area of wet-season lowland. There are four permanent irrigations and 102 conventional weirs. In spite of that, insufficient water is the major problem for agricultural production in dry season.

Crop production is active, but faced with many limitations; these are land constraints, water insufficiency, and inadequate use of purchased inputs. Limited lowland area seems to be most critical especially for those farmers who have just resettled from the mountainous areas. Farmers are dependent largely upon the rain in the wet season as the irrigation can not cover large area. Some farmers have to produce dry-season lowland rice in every other year because of the water use rule. In addition, farmers are reluctant to use purchased inputs such as improved varieties, fertilizer and insecticide. One reason is that they lack cash income to purchase these inputs, the other is these inputs are not largely locally available. Some farmers, however, exchange paddy for herbicide with the trader, which is apparently popular.

Two strata were identified-tractor-owning farmers (TOF) and non-tractor-owning farmers (NTF) - prior to collecting data. Tractor-owning farmers are those who have control/ownership over the tractor, regardless of individual or joint ownership. Shyamal and Melvin (1978) stated in their sampling methodology that non-tractor farm means farmers do not use tractor, but non-tractorowning farmers in this study means farmers who do not own but use tractor. Therefore, farmers who acquire the use of tractor by any means except ownership are classified into this stratum.

Data collection was done based on the participatory approach and the use of structured questionnaires by random sampling techniques. Thirty five observations were collected for TOF stratum. In this group, about six out of 35 farmers are joining tractor with the others. Fifty nine observations were collected for the NTF stratum. Six observations were, however, removed due to irrelevance and inconsistency. Strictly speaking, the analysis will focus on the farmers who produce lowland rice as the prime interest due to the fact that land preparation for upland rice production is always done under slashand-burn practice.

Variance analysis is largely used to determine the mean differences and its significance level in resources use and income, and regression analysis is tested to indicate the resource productivity between TOF and NTF. Qualitative analysis is also applied to find out the nature of tractor hire, and its impact on rice consumption of the hirers.

\section{RESULTS AND DISCUSSION}

\section{Household Characteristics}

The general characteristics of the sample households-TOF and NTF- are shown in the Table 1. These

Table 1. Characteristics of sample households by categories

\begin{tabular}{ccccc}
\hline & \multicolumn{2}{c}{ TOF } & \multicolumn{2}{c}{ NTF } \\
& N=35 & \multicolumn{2}{c}{ n=53 } \\
\hline Household Size (n) & $7.63^{* * * *}(0.38)$ & 6.24 & $(0.38)$ \\
Age of household head & 43.11 & $(1.70)$ & 45.27 & $(1.79)$ \\
Education level of head (\%) & & & & \\
Non school & 13 & & 20 & \\
Primary School & 74 & & 58 & \\
Lower secondary & 13 & & 20 & \\
Upper secondary & 0 & & 2 & \\
Males & & & & \\
Females & $3.89 * * *$ & $(0.22)$ & 3.01 & $(0.22)$ \\
Household Composition (n) & 3.74 & $(0.27)$ & 3.22 & $(0.22)$ \\
Primary Labor & 2.97 & $(0.21)$ & 2.58 & $(0.16)$ \\
Total family labor & $3.74 * *$ & $(0.24)$ & 3.15 & $(0.18)$ \\
& & & & \\
\hline
\end{tabular}

TOF=Tractor Owning Farmers; NTF=Non-Tractor-Owning Farmers

$* * *=\mathrm{p}<0.01, * * *=\mathrm{p}<0.05$. In parentheses is standard error.

Source: field survey, 2007 
Table 2. Machinery holding by TOF and NTF

\begin{tabular}{|c|c|c|c|c|c|}
\hline \multirow[t]{2}{*}{ TOF } & \multicolumn{5}{|c|}{ NTF } \\
\hline & $\mathrm{n}=35$ & $\%$ & & $\mathrm{n}=53$ & $\%$ \\
\hline Tractor only & 14 & 40 & Tractor only & 0 & 0 \\
\hline Tractor \& Micro-Rice Mill & 9 & 26 & Micro-Rice Mill & 4 & 8 \\
\hline Tractor \& Micro-Rice Mill \& Mini-Thresher & 11 & 31 & Micro-rice mill and Mini-Thresher & 0 & 0 \\
\hline Tractor \& Mini-Thresher & 1 & 3 & Mini-Thresher & 0 & 0 \\
\hline
\end{tabular}

Source: field survey, 2007

characteristics provide descriptive overview of households with regards to household size, age and education level of household head, and household labors.

Tractor-owning farmer households have a larger size with more males. The average household size is about eight and six persons among TOF and NTF households, respectively. The problem of illiteracy still exists especially among elderly people. About 13\% of household head of TOF and $20 \%$ of NTF have never been to school. Three fourths of TOF have been to primary school against 57\% of NTF. Further discussion is focused on higher percentage of NTF in secondary school than that of TOF. For one reason, six persons out of 53 NTF are part time farmers as the income of their main jobs are larger than income from the farm. Part-time farmers are normally teachers, government officers or those serving in the army. They are not primary labors in the households, but are their wives or children. The adoption of a tractor-hiring system may be influenced by factors of age, household size and education (Panin, 1995).

\section{Machinery Holdings}

Through participatory approach, tractor is recognized as one of the wealth indicators of the household. In other words, farmer who possesses tractor is normally ranked from medium-wealth to well-off households, meaning that they have better status in the community.

Tractor-owning farmers do not stop at the point they possess only tractor, $31 \%$ of them possesses and utilizes micro rice mill (12 HP) and mini thresher (6.5 HP)-which make them even more highly-mechanized (Table 2). On the other hand, non-tractor-owning farmers possess only micro rice mill but at less than $10 \%$, and none of them possesses any mini thresher. Some of farmers who own rice mill used to have tractor, but they had to sell it in order to obtain cash for health treatment.

It is worth recognizing that highly-mechanized farmers-farmers who possess all three machines in this case-firstly developed themselves from having only single machinery in which most of the case is tractor. These farmers hire out the tractor and obtain paddy as a fee of tractor hire. Every year they receive large amount of paddy; consequently, they have more income from the sale of paddy and more cash to purchase the other machines.

Virtually it is a big mistake to judge those without machines as low-mechanized. Despite lack of machines, farmers still have access to the services by many forms.

\section{Agricultural production}

Rice production

In 2007, a percentage of tractor-owning farmers producing lowland rice in both wet and dry seasons are almost three times higher than that of non-tractor-owning farmers, $26 \%$ vs. $9 \%$ (Table 3). In contrast, a number of farmers still doing a combination of wet-season lowland and upland rice production are higher for NTF group than for TOF group, $45 \%$ vs. $23 \%$. Non-tractor-owning farmers are usually small farmers who normally have small piece of lowland so their upland rice is still significant. In practice, some of tractor-owning farmers still depend on the upland rice too, but most of the cases are applied to those recently purchasing tractor.

Table 3. Rice production in 2007 by two categories

\begin{tabular}{lrrrrrr}
\hline & \multicolumn{2}{c}{ TOF } & & \multicolumn{2}{c}{ NTF } \\
\cline { 2 - 3 } \cline { 5 - 6 } \cline { 5 - 6 } Sole Lowland Wet & 15 & 42.9 & & 21 & 39.6 \\
Lowland Wet \& Dry & 9 & 25.7 & & 5 & 9.4 \\
Wet \& Dry \& Upland & 3 & 8.5 & & 3 & 5.6 \\
Wet \& Upland & 8 & 22.9 & & 24 & 45.2 \\
\hline
\end{tabular}

Source: field survey, 2007

Apparently farmers-owning tractor use land for rice production more extensively and intensively than those without tractor. This is partly because full access to

Table 4. Rice production by different ecosystems

\begin{tabular}{lllll}
\hline & \multicolumn{2}{c}{ TOF } & \multicolumn{2}{c}{ NTF } \\
\hline Wet-Season Lowland & & & & \\
$\quad$ Avg. cultivated area (ha) & $1.54^{* * * *}$ & $(0.14)$ & 0.82 & $(0.05)$ \\
Avg. Yield (t/h) & $2.77^{*}$ & $(0.13)$ & 2.48 & $(0.12)$ \\
Avg. Production (t) & $4.20^{* * *}$ & $(0.37)$ & 1.94 & $(0.14)$ \\
& & & & \\
Dry-Season Lowland & & & & \\
$\quad$ Avg. cultivated area (ha) & $1.12^{*}$ & $(0.12)$ & 0.77 & $(0.10)$ \\
$\quad$ Avg. Yield (t/h) & 3.24 & $(0.17)$ & 3.32 & $(0.35)$ \\
$\quad$ Avg. Production (t) & $4.07^{* * * *}(0.51)$ & 2.27 & $(0.31)$ \\
& & & & \\
Upland Rice & & & & \\
$\quad$ Avg. cultivated area (ha) & 0.57 & $(0.08)$ & 0.60 & $(0.16)$ \\
$\quad$ Avg. Yield (t/h) & 1.60 & $(0.31)$ & 1.30 & $(0.11)$ \\
$\quad$ Avg. Production (t) & 0.77 & $(0.08)$ & 0.78 & $(0.09)$ \\
\hline Annual Rice Production (t) $5.82^{* * * *}(0.61)$ & 2.68 & $(0.22)$ \\
\hline
\end{tabular}

$* * *=\mathrm{p}<0.01, *=\mathrm{p}<0.1$. In parentheses is Standard Error. 
machinery, mainly tractor, gives them greater incentive to expand the land and produce more.

As seen from Table 4, tractor-owning farmers grow wet season rice almost twice as of lowland area as do the non-tractor-owning farmers, 1.54 ha vs. 0.82 ha. However, both groups could not use their land optimally in the dry season because of inadequate water supply. The table further shows that TOF have higher yield of wet season lowland rice production than NTF $(p<0.1)$. However, the yield of dry-season lowland is not significantly different for both groups. Upland rice does not make any radical differences in area, yield and production. Certainly, in addition to operating larger area of lowland, TOF have much more annual production from their own field than have their counterparts—5.90 tons vs. 2.68 tons $(\mathrm{p}<0.01)$.

Regression Analysis of wet-season lowland rice production

Regression analysis is used to test the economic significance of resource use in wet-season lowland rice production. Taking into account the cultivated area and labor use in transplanting and harvesting (the most labor intensive activities), Cobb-Douglas production function is as follows:

\section{$\log (Y)=\log \left(\beta_{0}\right)+\beta_{1} \log \left(x_{1}\right)+\beta_{2} \log \left(x_{2}\right)+u$}

Where:

$$
\begin{aligned}
& \boldsymbol{Y} \text { - Total Production Quantity of wet-season } \\
& \text { Lowland (Kg) } \\
& \boldsymbol{X}_{\boldsymbol{1}} \text {-Wet-season Lowland Area Cultivated (ha) } \\
& \boldsymbol{X}_{2} \text { - Labor mainly family labor plus labor from } \\
& \text { Exchange/Hire in Transplant and Harvest (head) } \\
& \boldsymbol{u} \text { - Error terms } \\
& \boldsymbol{\beta}_{1}-\boldsymbol{\beta}_{2}-\text { Estimated Coefficients }
\end{aligned}
$$

Family-provided, hired or exchange labors are treated as single variable. About 25\% of TOF hired labor whereas less than $3 \%$ of NTF did. The variable of fertilizer or pesticide is not included in the regression because insignificant number of farmers applied it to their farm-about 10\% of farmers in both groups applied fertilizer or pesticide, also less than $10 \%$ of farmers used improved varieties in 2007 wet season rice production.

Table 5. Regression analysis of lowland wet rice production of TOF and NTF

\begin{tabular}{lll}
\hline \multicolumn{1}{c}{ Independent Variables } & TOF & NTF \\
\hline Intercept & 6.51 & 6.69 \\
$\log \left(\mathrm{X}_{1}\right)$ & $(0.70)^{* * * *}$ & $(0.47)^{* * *}$ \\
& 1.01 & 0.74 \\
$\log \left(\mathrm{X}_{2}\right)$ & $(0.09)^{* * *}$ & $(0.10)^{* * *}$ \\
& 0.32 & 0.25 \\
Observations & $(0.117)^{* *}$ & $(0.12)^{* *}$ \\
R-Squared & 35 & 53 \\
Adjusted R-Squared & 0.83 & 0.57 \\
\hline
\end{tabular}

$* * *, * * \& *$ indicate significance at $1 \%, 5 \%$ and $10 \%$ level, respectively.
The results of regression analysis shown in table 5 suggest that all of the independent variables have positive partial effects on dependent variable with goodness of fit of 0.83 for TOF and 0.57 for NTF. The coefficients for land for both TOF and NTF are the largest and significant at $1 \%$. Therefore, it is suggested by the regression that area expansion will result largely in increasing production quantity. However, TOF have higher land productivity than have NTF.

It is worth noticing that an aggregate of two coefficients for the regression of TOF is larger than one or precisely 1.3, which means that TOF have increasing returns to scale. In contrast, the sum of two coefficients for the regression of NTF is merely equal to one or 0.99, meaning that they have barely constant returns to scale.

At this present state, in the survey area, the tractorowning farmers are better in rice production than nontractor-owning farmers given the land productivity. Intuitively, ownership of tractor confers the control over the quality of job which probably affects the yield. There are, however, some variables that are not controlled for in the regression due to lack of data. These data are soil characteristics, irrigated area and hour use for tillage operation.

\section{Animal Husbandry}

Livestock production is also of important in the farming system in Laos. In addition to poultry, pig is found in most of the farms. Big animals such as buffalo and cows are still used for farm operation by small farmers who lack mechanical power. Buffalo are more raised and consumed than cow in the study area.

Table 6. Livestock holdings

\begin{tabular}{lcccccc}
\hline & \multicolumn{3}{c}{ TOF (n=35) } & \multicolumn{3}{c}{ NTF (n=53) } \\
& $\%$ & Mean & Std Err & $\%$ & Mean & Std Err \\
\hline Buffalo & 77 & $4.4^{* * *}$ & $(0.52)$ & 43 & 2.3 & $(0.27)$ \\
Cow & 26 & $3.4^{*}$ & $(0.72)$ & 13 & 1.9 & $(0.4)$ \\
Pig & 89 & $6.4^{* * *}$ & $(0.42)$ & 79 & 3.5 & $(0.41)$ \\
Goat & 29 & 8 & $(3.70)$ & 25 & 4 & $(0.93)$ \\
Poultry & 86 & $35.9^{* *}$ & $(3.52)$ & 85 & 24.2 & $(2.97)$ \\
\hline
\end{tabular}

$\%=$ Percentage of households

$* * *=\mathrm{p}<0.01, * *=\mathrm{p}<0.05$ and $*=\mathrm{p}<0.1$. In parentheses is Standard Error.

The table above shows that more than $75 \%$ of TOF have buffalo whereas only $43 \%$ of NTF do. The larger herd of buffalo is found in the TOF farm-the average holding for TOF is four heads compared to a pair of buffalo found in NTF, including calves. To tractor-owning farmers, buffalo are mainly raised for market purpose, and few of them are used in the farm as animal power. Lack of animal power is also attributed to the reason why farmers have adopted the tractor-hiring system.

Although the majority of farmers raise pigs, TOF have more pigs than NTF have: 6 heads vs. 4 heads. Moreover, a number of poultries — chickens and ducksare larger in TOF than in NTF- 36 vs. 24 heads.

Farm Income

The sale of paddy, cash crops and livestock contrib- 
Table 7. Income from farm

\begin{tabular}{|c|c|c|c|}
\hline & $\begin{array}{c}\text { TOF } \\
n=35\end{array}$ & \multicolumn{2}{|c|}{$\begin{array}{l}\text { NTF } \\
\mathrm{n}=53\end{array}$} \\
\hline \multicolumn{4}{|l|}{ Paddy (a) } \\
\hline n \& \% & $24 \quad \mathbf{6 9} \%$ & 18 & $34 \%$ \\
\hline Mean (Million Kip) & $6.58 * * * \quad(1.34)$ & 1.88 & $(0.38)$ \\
\hline \multicolumn{4}{|l|}{ Cash crops (b) } \\
\hline n \& \% & $24 \quad 6 \mathbf{6 9} \%$ & 28 & $52 \%$ \\
\hline Mean (Kip) & $1.59(0.26)$ & 1.15 & $(0.22)$ \\
\hline \multicolumn{4}{|l|}{ Livestock (c) } \\
\hline $\mathrm{n} \& \%$ & $24 \quad \mathbf{6 9} \%$ & 18 & $34 \%$ \\
\hline Mean (Million Kip) & $2.49 * * * \quad(0.52)$ & 0.89 & $(0.21)$ \\
\hline \multicolumn{4}{|l|}{$(a)+(b)+(c)$} \\
\hline$n \& \%$ & $34 \quad 97 \%$ & 46 & $87 \%$ \\
\hline Mean (Million Kip) & $7.53 * * * \quad(1.14)$ & 1.78 & $(0.23)$ \\
\hline
\end{tabular}

utes largely to cash income of households. The average annual farm income of TOF and NTF is summarized in the table below:

As can be seen from the table 7, tractor-owning farmers are more market-oriented in rice production than their counterparts-69\% vs. 34\%-due partly to operating larger area. Moreover, the value of the sale of paddy is about 6.58 million Kip for tractor-owning farmers whereas non-tractor-owning farmers could earn about 1.88 million kip. Descriptive analysis shows that TOF sold over $37 \%$ of their paddy from wet-season lowland (more than half of TOF marketed wet season rice), and about $87 \%$ of paddy from dry-season lowland (about $75 \%$ of TOF who produced dry-season lowland rice marketed their paddy). On the other hand, non-tractorowning farmers who are largely producing at subsistence level especially tractor-hiring farmers who have to pay paddy for tractor hire sold about less than 30\% of their paddy from wet-season lowland (only 25\% of NTF marketed their wet-season lowland rice though), and $74 \%$ of paddy from dry-season lowland (about 50\% of NTF who produced dry-season lowland rice marketed their paddy).

Another significant difference is the income from livestock. Big animals are attributed to the large share of income from livestock. Tractor-owning farmers earned about 2.49 million kip whereas non-tractor-owning farmers could make about 0.89 million kip from livestock. Buffalo makes good cash, and the demand for buffalo is also high. Therefore, TOF who have larger herd of buffalo earned much more cash from livestock. Pigs are also one of the animals that give regular income. Farmers always sell pigs when cash is urgently needed.

The maximum annual farm income from the sale of paddy, cash crops and livestock is found in TOF (7.53 million kip), and it is triple when compared to annual farm income of NTF (1.78 million kip). In other words, there is a huge income gap between these two categories of farmer. The sale of paddy contributes the most in the share of income for both groups. The second most important source of income for tractor-owning farmers is from livestock in which the cash earned from selling livestock is larger than that from cash crops (maize, peanut and sesame), whereas it is the other way round for non-tractor-owning farmers.

\section{Tractor Service by Custom Hire}

Custom hire always comes with the tractor operators. Farmer often hires a tractor from the farmer in the same village or adjacent field. Prior to the tillage operation, tractor-hiring farmer will seek and form a deal, always oral agreement, with the tractor-owning farmer who is engaged in the custom hire service, or vice-versa. Then, the tractor-hiring farmer must state the amount of seed s/he will plant this growing season as the basis for calculating the fee of the tractor hire. When the tractor is being operated, tractor-hiring farmers are usually in charge of the meals, drinks and cigarettes for the operators.

Many advantages are offered to farmers purchasing the custom hire. Timeliness, effective management, time and labor saved are the primary advantages. Hired tractor must always be available to the purchaser after the deal has been made. Basically, hired tractor comes on designated day to finish each activity. Therefore, works are always done according to the planned schedule especially transplanting. Moreover, farmer knows exactly the cost of operation. They have no responsibility on the tractor as every cost is borne by the owner. Secondly, less time for tillage operation means more time for the other activities. However, they seem to spend those times on farming activities, only few of them spend those times on income-generating activities. During wet season, weeding in the upland field is a common task; exchanging labor with other farmers is also practiced. Finally, tractor-hiring farmers are not involved in the tillage operation which is dealt by the operators, unless they want to. So farmers are less susceptible to the illness or injuries resulting from the tillage operation.

Quality of work, however, has always been the principal concern. More than $65 \%$ of tractor-hiring farmers said that the hired tractor does not produce as good job as does the buffalo. For one reason, tractor-owning farmer does care more about the tractor rather than good performance of work. Specifically, the dieselincluding option often produces the poor job because the faster the job is done the fewer liters of diesel is consumed. The other disadvantage is high cost.

Table 9. Tractor Fee per one Kilogram $(K g)$ of seed planted (Unit: Paddy)

\begin{tabular}{lclc}
\hline \multicolumn{2}{c}{ Diesel Included } & \multicolumn{2}{c}{ Diesel Excluded } \\
& $\mathrm{Kg}$ & & $\mathrm{Kg}$ \\
\hline \multirow{2}{*}{ Mean } & $\mathbf{2 2}$ & Mean & $\mathbf{1 7}$ \\
Minimum & 18 & Minimum & 15 \\
Maximum & 25 & Maximum & 20 \\
\hline
\end{tabular}

Source: field survey 2007 
Normally, tractor hire service offers two methods for payment: by paddy (after harvest)—diesel-including or diesel-excluding-or by cash (after work). Dieselincluding means tractor-owning farmer is responsible for every cost in the tillage operation including the diesel cost. Certainly, the fee of this option is high. In contrast, diesel-excluding option is the one that tractor-hiring farmers have to be responsible for the diesel cost incurred in the tillage operation, excluding travel to and from the field. The fee of tractor hire is cheaper but another cost is also charged-diesel cost.

The amount of paddy paid to the tractor owner is dependent on the amount of seed sown. For instance, if farmer $\mathbf{K}$ sows $50 \mathrm{~kg}$ of seed to plant in one hectare for traditional varieties, and wishes to hire tractor including diesel for tillage operation, the farmer $\mathrm{K}$ will have to pay about $50 \times 22=1100 \mathrm{~kg}$. In 2007 , the paddy price at farm gate is $1800 \mathrm{kip} / \mathrm{kg}$ (cost of tillage operation is, therefore: $1100 \times 1800=1,980,000 \mathrm{Kip}$ ). However, one hectare, in normal condition, yields about 2.5-3.5 Tons/ha, if not less than that, so the paddy paid for hiring tractor is about a third of total production. Some farmers have to state the lesser amount of seed sown in order not to pay a large amount of paddy for tractor hire.

Majority of tractor-hiring farmers choose the dieselexcluding option and rather buy diesel than exchange by paddy. Farmers who lack cash usually obtain diesel from the trader with high exchange rate $(200 \mathrm{~kg}$ of paddy per 20 liters of diesel) and return by paddy after harvesting. It does not make much different from the previous option if farmers exchange diesel by paddy, because 25 liters of diesel is needed for tillage operation in one hectare; if farmers exchange paddy for diesel, they have to trade $10 \mathrm{~kg}$ of paddy for 1 liter of diesel. In contrast, if farmers buy diesel, it costs 9500 kip/liter. By choosing this method, tractor-hiring farmer is better off than the former because the cost of tractor hire per one hectare is $850 \mathrm{~kg}$ plus 237,500 kip (totally 1,767,500 kip).

Generally farmer who chooses to pay by cash has to pay money right after the job has been done. Paying by cash is also calculated in the same basis about 18,000 $\mathrm{kip} / \mathrm{kg}$ including diesel per one kilogram of seed (totally $18000 \times 50=900,000 \mathrm{kip}$ ). Therefore, paying by cash is best off, because the cost of tractor hire per hectare is 900,000 kip compared to 1,980,000 Kip paid by paddy. However, this value does not account for the cost of lunches, drinks and cigarettes that tractor-hiring farmers have to prepare for the operator. Some tractor-owning farmers also value the fee by the farm size, usually in monetary term.

Tractor hire service does not stop only at the tillage operation, but also for transport of rice. Depending on how good relationship between tractor-owning farmer and tractor-hiring farmer is, sometimes the paddy is transported for free. If charged, the fee is usually about one bag per 12 to 15 bags of paddy depending on the trailer size (about 7\% out of the total transported).

Sixty percent of tractor-owning farmers still provide custom hire service in 2007. The paddy they received annually from hiring tractor out was about $1370 \mathrm{~kg}$ (both including and excluding diesel). Usually paddy they received from tractor-hiring farmers is largely marketed. Therefore, paddy is the major source of income for tractor-owning farmers.

\section{Impact of tractor hire on rice consumption}

Approximately 90\% of non-tractor-owning farmers acquired the use of tractor by custom hire. The rest of them exchanged their own labor for the use of tractor (exchange work).

Not surprisingly, tractor hire is one of the factors affecting rice shortage as answered by farmers themselves. In addition to small lowland area, farmers have suffered from the high cost of land preparation. Some farmers experienced the worst in the very low production season when they had to add their upland rice for the fee of tractor hire. Tractor-hiring farmers have paid about $30 \%$ or about $630 \mathrm{~kg}$ of the total production for tractor hire, if everything is paid by paddy. This affects largely the security of their rice consumption in the household. In the past, the cost of land preparation (hired buffalo) and hired labor for lowland rice farmers accounted for only 10\% of total production (Phantavong et al., 1994).

About 70\% of farmers who acquired the use of tractor by custom hire paid the fee by paddy due to lack of cash, and more than $65 \%$ of them have a problem of rice shortage. It is reported that some farmers with small piece of land have given up lowland rice production because they think it is not worth producing if tractor is hired, and go back to produce more upland rice.

Farmers respond to rice shortage by borrowing rice, purchasing rice or eating substitute crops. Borrowing rice can be done in two ways-borrowing from relatives or friends and borrowing from village rice bank. The other coping strategy is to purchase rice. Sources of fund are usually from the sale of cash crop, livestock and non-timber forest products (NTFPs), and some from wage labor. Few farmers still eat substitute crops like cassava and sweet potato.

\section{CONCLUSIONS}

Although the farm mechanization in general is low, tillage operation is increasingly mechanized. Several factors are attributed to the increasing use of tractor among farmers. Agricultural mechanization policies encourage distributors and farmers to import and use more machinery. The timeliness in operation is convincing farmers to invest in long term farm technology-purchasing a tractor, thresher and rice mill. Lack of buffalo or decreasing number of trained buffalos and skilled operators are one of the factors. Being not knowledgeable in driving buffalo with drawn implements of farmers who used to practice slash and burn cultivation in upland area leaves them no choice but to use tractor in the lowland rice production.

Among the farmers who introduced tractor into the production system, TOF are better in terms of rice production in which they have better control over the quality 
of job. In contrast, more than half of NTF who acquired the use of tractor hire and paid by paddy have a problem of rice shortage in the household resulting partly from high cost of tractor hire. Therefore, it can be concluded that, at this present state, the benefits from farm tractorization could be optimally realized by ownership, unless the quality of job performed by hired tractor is improved and the fee paid by paddy is cheaper.

Improvement of data collection and database not only for tractor but also the other machineries used in the farm will strengthen the development of farm mechanization. Provision of favorable environment to NTF so that they can develop themselves and become TOF eventually is advocated. Although if a number of farmers purchasing tractor are increasing which may result in lesser demand for tractor hire, the social benefits as a whole are improved. Intervention on the tractor hire especially the fee paid by paddy could improve the situation of food security of smallholder farmers. Alternatively, effective promotion of cash crop, livestock and nonfarm-income-generating activities is recommended so that farmers can pay by cash which is the best off option. Besides, experiences from tractor-owning farmers showed that buffalo is the major source of fund to purchase tractor. Promotion of active village vaccination is, therefore, of crucial and urgent.

\section{REFERENCES}

Akinola, A. A. 1986 Government Tractor Hire Service Scheme as a Tractorization policy in Africa: The Nigerian Experience. Agric. Admin. \& Extension, 25: 63-71

Binswanger, H. P 1978 The Economics of Tractors in South Asia:
An Analytical Review. Agricultural development Council, New York and ICRISAT, Hyderabad, India

Buckett, M. 1988 An Introduction to Farm Organization and Management. Pergamon Press, Oxford

CPI-NSC (Committee for Planning and Investment-National Statistics Center) 2005 Population and Housing Census 2005. Vientiane, Lao PDR

Government of Lao PDR 1998 Lao Expenditure and Consumption Survey 1997/1998 (LECS 2), National Statistics Center. Vientiane, Lao PDR

Government of Lao PDR 2003 Lao Expenditure and Consumption Survey 2002/2003 (LECS 3), National Statistics Center. Vientiane, Lao PDR

Ministry of Agriculture and Forestry (MAF) $2000 \quad$ Lao Agricultural Census 1998/99. Vientiane, Lao PDR

Panin, A. 1994 Empirical evidence of mechanization effects on smallholder crop production systems in Botswana. Agricultural Systems, 47: 199-210

Phantavong, S., J. M. Schiller and V. Sisaphone 1994 Applied Farming systems research in the rainfed lowlands of the Lao PDR, Lao IRRI

Roy, S. and M. G. Blase 1978 Farm tractorization, Productivity and labor employment: A case study of India Punjab. Journal of Development Studies, 14(2): 193-209

Singh, G. and S. Khoune 2001 Agricultural Mechanization in Laos: A Case Study in Vientiane Municipality. Agricultural Mechanization in Asia, Africa and Latin America, 32(2): 55-61

Sydney C. James and Phillip R. Eberle 2000 Economic \& Business Principles In Farm Planning \& Production. Iowa State University Press

Tetlay, K., D. Byerlee and Z. Ahmad 1990 Role of Tractors, Tubewells and Plant Breeding in Increasing Cropping Intensity in Pakistan's Punjab Agricultural Economics, 4: 13-25

Ulluwishewa, R. 1987 Factors Affecting the Mechanization of the Tillage Operation of Paddy Fields in Sri Lanka: A Geographical Perspective. GeoJournal, 15(4): 393-398

UNDP (United Nations Development Programme) 2006 National Human Resource Development Report, Lao PDR 2006: International trade and human development. Vientiane: UNDP 